\title{
Pengaruh Model Pembelajaran Reciprocal Teaching Berbasis Penilaian Kinerja Terhadap Kompetensi Pengetahuan IPA
}

\author{
Ni. K. P. Yusita ${ }^{\text {* }}$, I W. Darsana², IB. G. S. Abadi ${ }^{3}$ \\ 1,2,3 Jurusan Pendidikan Guru Sekolah Dasar (PGSD), Universitas Pendidikan Ganesha, Singaraja, Indonesia.
}

\section{A R T I C L E I N F O}

Article history:

Received 18 May 2018

Received in revised form 9 June 2018

Accepted 10 July 2018

Available online 21 August 2018

\section{Kata Kunci: \\ reciprocal teaching, penilaian kinerja, kompetensi pengetahuan $I P A$}

Keywords: reciprocal teaching, performance assessment, science competence.

\begin{abstract}
A B S T R A K
Penelitian ini bertujuan untuk mengetahui pengaruh model pembelajaran Reciprocal Teaching berbasis penilaian kinerja terhadap kompetensi pengetahuan IPA siswa kelas IV SD Gugus I Kecamatan Gianyar tahun pelajaran 2017/2018. Jenis penelitian ini adalah eksperimen semu dengan menggunakan rancangan kelompok nonequivalent control group design. Populasi penelitian ini seluruh siswa kelas IV SD Gugus I Kecamatan Gianyar yang berjumlah 440 siswa. Sampel diambil dengan teknik random sampling, dan diperoleh kelas IV ${ }^{A}$ di SD Negeri 7 Gianyar sebagai kelompok eksperimen dan kelas IV di SD Negeri 6 Gianyar sebagai kelompok kontrol dengan jumlah siswa masing-masing kelompok 30 siswa. Pengumpulan data dilakukan dengan metode tes, jenis tes yang digunakan adalah tes objektif pilihan ganda biasa. Data yang diperoleh dianalisis menggunakan analisis uji-t separated varians. Hasil analisis data diperoleh $t_{\text {hitung }}=7,067>t_{\text {tabel }}=$ 2,000 pada taraf signifikansi $5 \%$ dan $\mathrm{dk}=58$, maka $\mathrm{H}_{0}$ ditolak dan $\mathrm{H}_{\mathrm{a}}$ diterima. Adapun nilai rata-rata kompetensi pengetahuan IPA kelompok eksperimen $\bar{X}=0,46$, sedangkan rata-rata kompetensi pengetahuan IPA kelompok kontrol $\bar{X}=0,26$. Berdasarkan hasil penelitian tersebut dapat disimpulkan bahwa model pembelajaran Reciprocal Teaching berbasis penilaian kinerja berpengaruh terhadap kompetensi pengetahuan IPA siswa kelas IV SD Gugus I Kecamatan Gianyar Tahun Pelajaran 2017/2018
\end{abstract}

\begin{abstract}
A B S T R A C T
This study aimed to know about the affect of reciprocal teaching model based on performance assessment againts the competence science knowledge of fourth grade students of elementary school Gugus I Gianyar district in 2017/2018. This research type is quasi experiment research with nonequivalent control group design. The population of this study is all students of class IV elementary school Gugus I Gianyar district which 440 students. Sample were taken by random sampling technique, so that the IVA class in elementary school 7 Gianyar as the experimental group and the IVB class in elementary school 6 Gianyar as the control group with the total students in each group of 30 students. The data collection was done by the test method, the type of test was the usual multiplechoice objective test. The data obtained were analyzed using t-test analysis of separated variance. The result of data analysis is tcount $=7.067>\mathrm{ttable}=2,000$ at $5 \%$ significance and $\mathrm{dk}=58$, then $\mathrm{H} 0$ is rejected and $\mathrm{Ha}$ accepted. The average value of science knowledge competence of the experimental group $\mathrm{X}^{-}=0,46$, while average science knowledge competence of control group $\mathrm{X}^{-}=0,26$. Based on the results of this research, it can be concluded that the Reciprocal Teaching learning model based on performance assesment affect the knowledge competence of science students fourth grade students of elementary school Gugus I Gianyar districts year 2017/2018
\end{abstract}




\section{Pendahuluan}

Pendidikan dapat dikatakan sebagai suatu usaha yang dilaksanakan oleh keluarga, masyarakat, dan tentunya pemerintah melalui kegiatan pengajaran, bimbingan, serta pelatihan, baik melalui pendidikan formal di sekolah, maupun pendidikan non formal di luar sekolah. Namun, di dalam dunia pendidikan sendiri terdapat berbagai permasalahan. Secara global permasalahan pendidikan yang dihadapi yaitu semakin tingginya tingkat buta huruf di dunia. Sehingga terjadinya kendala di beberapa negara untuk bersaing secara global.

Contohnya saja Indonesia yang sampai saat ini masih merupakan negara berkembang yang sesungguhnya memiliki potensi sumber daya alam maupun sumber daya manusia dalam kuantitas tinggi, namun permasalahan pendidikan di Indonesia yang masih menjadi kendala yaitu kurangnya akses untuk memperoleh pendidikan terutama di daerah terpencil yang ada di Indonesia. Salah satu daerah di Indonesia yaitu Provinsi Bali, terkenal sebagai daerah tujuan wisata dunia. Banyak wisatawan dari berbagai belahan dunia datang ke Bali, bahkan ada yang memilih menetap di Bali. Namun pendidikan di Bali masih belum merata di beberapa kabupaten, bahkan masih banyak kasus anak putus sekolah akibat dari biaya pendidikan yang tinggi dan akses untuk memperoleh pendidikan yang kurang memadai.

Upaya peningkatan kualitas pendidikan terus dilakukan guna menciptakan sistem pendidikan yang berkualitas. Dalam rangka menerapkan pendidikan yang berkualitas, Pemerintah Indonesia menerapkan kurikulum tahun 2013. Karena peran kurikulum sangat penting sebagai pedoman dalam proses pembelajaran di sekolah. Penyempurnaan kurikulum tersebut didasari pada kesadaran bahwa perkembangan dan perubahan yang terjadi menuntut perlunya perbaikan sistem pendidikan nasional. Termasuk juga penyempurnaan kurikulum untuk mewujudkan masyarakat yang mampu bersaing dan menyesuaikan diri dengan perubahan.

Saat ini kurikulum yang diterapkan di Sekolah Dasar yaitu Kurikulum 2013. Berdasarkan UndangUndang Nomor 20 Tahun 2003 Pasal 1 butir 19 tentang Sistem Pendidikan Nasional, dinyatakan bahwa kurikulum adalah seperangkat rencana dan peraturan mengenai tujuan, isi dan bahan pelajaran serta cara yang digunakan sebagai pedoman penyelenggaraan kegiatan pembelajaran untuk mencapai tujuan pendidikan. Kurikulum 2013 menuntut kemampuan guru untuk berpengetahuan dan memiliki empat komponen dasar kompetensi guru, yaitu kompetensi pedagogik, kompetensi sosial, kompetensi kepribadian, dan kompetensi profesional. Dalam pembelajaran, guru berperan sebagai fasilitator dan siswa aktif untuk membangun pengetahuannya dari berbagai sumber belajar.

Berdasarkan hasil wawancara yang dilakukan dengan guru kelas IV SD Gugus I Kecamatan Gianyar pada tanggal 10 Januari 2018, permasalahan yang sering terjadi dalam pembelajaran khususnya di SD Gugus I Kecamatan Gianyar adalah masalah proses pembelajaran yang kurang mampu mengembangkan kemampuan berpikir siswa karena dalam melaksanakan proses pembelajaran siswa masih bergantung pada penjelasan yang diberikan oleh guru sehingga pembelajaran yang berlangsung di kelas hanya diarahkan pada kemampuan siswa untuk menghafal suatu informasi tanpa memahaminya. Dari berbagai muatan materi, hal tersebut juga menimpa salah satu muatan materi IPA dimana dalam proses pembelajarannya masih banyak dilaksanakan secara konvensional. Artinya, proses pembelajaran masih berpusat pada guru. Apabila hal ini terus terjadi, siswa tidak akan mencapai kompetensi pengetahuan yang diharapkan khususnya pada pembelajaran yang bermuatan materi IPA.

"Ilmu Pengetahuan Alam (IPA) atau dalam bahasa Inggris yaitu natural science, artinya ilmu yang mempelajari peristiwa-peristiwa yang terjadi di alam ini" (Samatowa, 2011:3). IPA sangat penting diajarkan di sekolah dasar, karena IPA mampu melatih anak untuk berpikir kritis, kreatif dan objektif. Menurut Susanto (2013:167), "Sains atau IPA adalah usaha manusia dalam memahami alam semesta melalui pengamatan yang tepat pada sasaran, serta menggunakan prosedur, dan dijelaskan dengan penalaran sehingga mendapatkan suatu kesimpulan". Pembelajaran bermuatan materi IPA memberikan kesempatan kepada siswa untuk mengembangkan rasa ingin tahu secara alamiah, sehingga membentuk kepribadian siswa dalam mengembangkan kompetensi pengetahuannya. Oleh karena itu, kegiatan pembelajaran dikelas khususnya pada pembelajaran bermuatan materi IPA perlu dikembangkan dari segi pelaksanaan pembelajaran. Dalam hal ini perlu dilakukannya inovasi dalam menyajikan materi pembelajaran agar dapat menarik minat sehingga siswa termotivasi untuk belajar dan membangun pengetahuannya dengan meggunakan salah satu model pembelajaran yaitu model pembelajaran reciprocal teaching.

Suastra (2017:143) menyatakan, "model pembelajaran adalah kerangka konseptual yang melukiskan prosedur yang sistematik dalam mengorganisasi pengalaman belajar untuk mencapai tujuan belajar tertentu dan berfungsi sebagai pedoman bagi guru dalam merencanakan dan melaksanakan aktivitas belajar mengajar. Saat ini, model pembelajaran banyak dikembangkan. Setiap model pembelajaran akan membantu merancang suatu pembelajaran, sehingga setiap siswa bisa mencapai 
tujuan pembelajaran. Masing-masing model pembelajaran tersebut, telah memuat sintak yang harus diperankan oleh guru dan siswa. Karena, "guru dan siswa sama-sama saling belajar dan membangun dinamika kelas yang hangat dan menyenangkan” (Kurniasih dan Sani, 2017).

Model pembelajaran reciprocal teaching dikembangkan pertama kali oleh Palincsar. Esensi dari model pembelajaran ini adalah siswa berperan sebagai guru untuk menyampaikan materi kepada temantemannya, sementara itu guru lebih berperan sebagai fasilitator dan pembimbing. Resnick (dalam Lestari dkk, 2017: 69) menyatakan bahwa "pembelajaran reciprocal adalah suatu kegiatan pembelajaran yang dilakukan oleh siswa meliputi membaca bahan ajar, merangkum, mengajukan pertanyaan, menyelesaikan masalah dan menyusun prediksi".

Pada model pembelajaran reciprocal teaching siswa diberikan kesempatan untuk mempelajari materi terlebih dahulu, kemudian siswa menjelaskan kembali materi yang dipelajari kepada siswa yang lain. Sementara itu, guru lebih berperan sebagai fasilitator dan pembimbing yang melakukan scaffolding. Scaffolding adalah "bimbingan yang diberikan oleh orang yang lebih tahu kepada orang yang kurang tahu atau belum tahu" (Shoimin, 2014:153). Melalui model pembelajaran reciprocal teaching siswa diajarkan empat strategi pemahaman pengaturan diri spesifik yaitu (question generating) pengajuan pertanyaan, (clarifying) klarifikasi, (predicting) prediksi, dan (summarizing) perangkuman.

Kekuatan-kekuatan model reciprocal teaching menurut Shoimin, (2014:154), yaitu sebagai berikut: (1) Melatih kemampuan siswa belajar mandiri sehingga kemampuan dalam belajar mandiri dapat ditingkatkan; (2) Melatih siswa untuk menjelaskan kembali materi yang dipelajari kepada pihak lain. Dengan demikian, penerapan pembelajaran ini dapat dipakai siswa dalam mempresentasikan idenya; (3) Orientasi pembelajaran adalah investigasi dan penemuan. Dengan menemukan dan menyelidiki sendiri konsep yang sedang dibahas, siswa akan lebih mudah dalam mengingat suatu konsep. Pengertian siswa tentang suatu konsep pun merupakan pengertian yang benar-benar dipahami oleh siswa.

Selain menggunakan model reciprocal teaching untuk meningkatkan penguasaan kompetensi pengetahuan IPA siswa, perlunya upaya untuk mengamati kegiatan siswa dalam melakukan kegiatan yaitu dengan menggunakan penilaian autentik. Penilaian merupakan "istilah umum yang didefinisikan sebagai sebuah proses yang ditempuh untuk mendapatkan informasi yang digunakan untuk membuat keputusan mengenai aktivitas para siswa" (Uno dan Satria, 2014:1). Penilaian dalam pembelajaran adalah suatu proses pengumpulan informasi yang berkaitan dengan pengambilan keputusan oleh guru untuk memperbaiki proses dan hasil belajar siswa. Salah satu fungsi penilaian yaitu sebagai upaya pendidik untuk menemukan kelemahan dan kekurangan dalam pembelajaran yang telah dilakukan atau sedang berlangsung. Pembelajaran reciprocal teaching dirangkaikan dengan penilaian kinerja. Penilaian kinerja atau unjuk kerja merupakan "penilaian yang dilakukan dengan mengamati kegiatan peserta didik dalam melakukan sesuatu" (Uno dan Satria, 2014:19). Penilaian ini digunakan untuk menilai ketercapaian kompetensi yang menuntut siswa menunjukkan unjuk kerja. Hal ini juga bertujuan untuk memantau siswa dalam proses pembelajaran.

Penilaian kinerja mempunyai beberapa kelebihan. Menurut Kunandar (2014:265-266), beberapa kelebihan dari penilaian kinerja sebagai adalah (1) Dapat menilai kompetensi yang berupa keterampilan (skill); (2) Dapat digunakan untuk mencocokkan kesesuaian antara pengetahuan mengenai teori dan keterampilan di dalam praktik, sehingga informasi penilaian menjadi lengkap; (3) Dalam pelaksanaan tidak ada peluang peserta didik untuk menyontek; (4) Guru dapat mengenal lebih dalam lagi tentang karakteristik masing-masing peserta didik; (5) Memotivasi peserta didik untuk aktif. Untuk mengamati kinerja peserta didik dalam proses pembelajaran, guru dapat menggunakan alat atau instrumen lembar pengamatan atau observasi dengan daftar cek (check list) dan skala penilaian (rating scale).

IPA yang merupakan ilmu yang mempelajari gejala-gejala atau peristiwa yang terjadi di alam, perlu diajarkan dengan suasana kelas yang aktif dan menyenangkan. Sehingga model reciprocal teaching sebagai salah satu cara untuk menciptakan suasana kelas yang aktif, karena model ini memberikan kesempatan bagi siswa untuk berperan sebagai guru kepada teman-temannya, dan guru sendiri sebagai fasilitator. Dalam prosesnya model reciprocal teaching memiliki empat strategi yaitu, membuat pertanyaan (question generating), mengklarifikasi permasalahan (clarifying), pengembangan (predicting), dan menyimpulkan materi (summarizing).

Tujuan penelitian ini adalah untuk mengetahui pengaruh model pembelajaran reciprocal teaching berbasis penilaian kinerja terhadap kompetensi pengetahuan IPA siswa kelas IV SD Gugus I Kecamatan Gianyar Tahun Pelajaran 2017/2018. 


\section{Metode}

Penelitian dilaksanakan di SD Gugus I Kecamatan Gianyar Tahun Pelajaran 2017/2018 yaitu di SD Negeri 7 Gianyar sebagai kelas eksperimen yang beralamat di jalan Patih Jealntik, Gianyar dan SD Negeri 6 Gianyar sebagai kelas kontrol yang beralamat di jalan Kaliasem, No.7 Gianyar.

Jenis penelitian yang dilakukan dalam penilitian ini adalah penelitian kuantitatif dengan desain eksperimen semu (quasi experiment). Dalam pemilihan subjek penelitian, peniliti tidak selalu dapat melakukan pemilihan subjek secara random (individual random). Dalam penetapan random (random assignment) peneliti tidak memungkinkan memilih dan memilah subjek sesuai dengan rancangannya, yang berarti tidak membentuk kelompok baru (Setyosari: 2015). Desain eksperimen yang digunakan adalah Non Equivalent Control Group Design.

Dalam rancangan penilitian non-equivalent control group design, ada dua kelompok subjek, satu kelompok mendapat perlakuan dan satu kelompok lagi sebagai kelompok kontrol. Sebelum pemberian perlakuan, dilakukan pengukuran awal atau pretest terhadap kedua kelompok tersebut. Selanjutnya, pada kelompok eksperimen diberikan perlakuan $(\mathrm{X}$ ) yaitu, model pembelajaran reciprocal teaching berbasis penilaian kinerja, sedangkan untuk kelas kontrol dibelajarkan menggunakan pembelajaran konvensional. Setelah itu, kedua kelompok dilakukan pengukuran pasca pemberian perlakuan atau pascates.

Subjek yang akan diteliti diistilahkan sebagai populasi dan sampel. Dalam suatu penelitian populasi dan sampel memiliki hubungan yang saling keterkaitan. Menurut Sugiyono (2016:61) "populasi adalah wilayah generalisasi yang terdiri dari obyek atau subyek yang menjadi kuantitas dan karakteristik tertentu yang ditetapkan oleh peneliti untuk dicari dan kemudian ditarik kesimpulannya". Sedangkan menurut Setyosari (2015:221) "populasi adalah keseluruhan dari objek, orang, peristiwa atau sejenisnya yang menjadi perhatian dan kajian dalam penelitian". Berdasarkan pendapat kedua ahli tersebut dapat disimpulkan bahwa populasi pada prinsipnya adalah semua anggota atau keseluruhan dari objek individu yang memiliki karakteristik tertentu yang ingin diteliti oleh peniliti lalu dipelajari dan ditarik kesimpulannya. Jumlah populasi dari penelitian ini adalah 438 orang siswa, dengan rincian sebaran pada tiap sekolah sebagai berikut.

Suatu penelitian tidak memungkinkan mempelajari semua yang ada dalam populasi. Hal ini dikarenakan keterbatasan dana, tenaga, dan waktu, maka dapat digunakan sampel yang diambil dari populasi tersebut. Menurut Sugiyono (2017:81) "Sampel adalah bagian dari jumlah dan karakteristik yang dimiliki oleh populasi tersebut".

Teknik pengambilan sampel pada penelitian ini menggunakan teknik random sampling. Random sampling "merupakan teknik penarikan sampel secara sederhana dengan cara acak atau random" (Dantes, 2012:41). Dengan demikian, peneliti menentukan kelompok yang akan dijadikan sampel dengan melakukan undian kertas yang berisikan nama kelas di masing-masing sekolah. Pengambilan undian dilakukan secara acak dengan mengambil 2 (dua) undian tanpa mengembalikan undian pertama yang telah diambil.

Pengundian pertama dilakukan untuk menentukan dua kelompok yang akan dijadikan sampel. Kedua kelompok diberikan pretest untuk menyetarakan secara akademik. Kedua kelompok yang sudah dinyatakan setara akan dilakukan pengundian kembali untuk menentukan kelas yang akan dijadikan kelompok eksperimen dan kelompok kontrol. Setelah pengundian tersebut, kelompok eksperimen yang diberikan perlakuan dengan menerapkan model pembelajaran reciprocal teaching berbasis penilaian kinerja dan kelompok kontrol yang dibelajarkan secara konvensional. Dari hasil pengundian yang dilakukan diperoleh kelompok sampel yaitu kelas IVa SD Negeri 7 Gianyar sebagai kelompok eksperimen dan kelas IVb SD Negeri 6 Gianyar sebagai kelompok kontrol.

Tahapan eksperimen melalui tiga tahapan, yaitu tahap persiapan, tahap pelaksanaan, dan tahap akhir eksperimen. Pada tahap persiapan kegiatan yang dilakukan oleh peneliti yaitu mewawancarai ketua gugus I Kecamatan Gianyar dan wali kelas IV untuk mengetahui ada atau tidaknya kelas unggulan di SD Gugus I Kecamatan Gianyar, mempersiapkan dan mencermati buku guru bersama wali kelas terkait materi yang akan diujicobakan dalam penelitian, menyusun serta mengkonsultasikan Rencana Pelaksanaan Pembelajaran (RPP), mempersiapkan pembelajaran reciprocal teaching berbasis penilaian kinerja, mengkonsultasikan instrumen penelitian prates dan pascates bersama wali kelas dan dosen pembimbing, mengadakan uji coba instrumen penelitian soal pascates, melakukan pengundian untuk menentukan kelompok yang akan dijadikan kelompok eksperimen dan kelompok kontrol, memberikan pretest kepada dua kelompok kelas yang diundi untuk kesetaraan kelompok. Untuk kesetaraan kelompok menganalisis data pretest dengan teknik uji t. Tahap pelaksanaan eksperimen adalah memberikan perlakuan pada kelas eksperimen berupa model pembelajaran reciprocal teaching berbasis penilaian kinerja. Pada kelas kontrol dibelajarkan menggunakan pembelajaran konvensional. Perlakuan diberikan sebanyak 6 (enam) kali di kelas eksperimen dan telah disesuaikan dengan jam pelajaran terkait dmuatan 
materi IPA. Diakhir penelitian, kegiatan yang ditempuh adalah memberikan posttest untuk kelompok eksperimen dan kelompok kontrol. Hasil dari posttest dianalisis untuk mengetahui adanya pengaruh model pembelajaran reciprocal teaching berbasis penilaian kinerja terhadap kompetensi pengetahuan IPA.

Metode yang digunakan dalam dalam pengumpulan data penelitian ini adalah metode tes. Arikunto (2015:46) menyatakan "tes merupakan serentetan pertanyaan atau latihan atau alat lain yang digunakan untuk mengukur keterampilan, pengetahuan, intelegensi, kemampuan atau bakat yang dimiliki oleh individu atau kelompok". Pada penelitian ini jenis tes yang digunakan adalah bentuk tes pilihan ganda biasa. Setelah instrumen penelitian tersusun kemudian dilakukan uji coba instrument penelitian. Kompetensi pengetahuan yang dikembangkan dalam penelitian ini terdiri dari 50 butir soal. Uji coba instrument yang dilakukan adalah uji validitas empirik oleh pendapat ahli yang selanjutnya dianalisis dengan uji validitas, uji daya beda, uji tingkat kesukaran, dan uji reliabilitas.

Selanjutnya pelaksanaan penelitian dilakukan dengan perlakuan terhadap masing kelompok sampel yakni model pembelajaran reciprocal teaching berbasis penilaian kinerja pada kelompok eksperimen dan pembelajaran konvensional pada kelompok kontrol. Setelah diberikan perlakuan, kedua kelompok sampel tersebut diberikan posttest. Hal tersebut dilakukan untuk memperoleh kompetensi pengetahuan IPA. Kemudian nilai posttest dan pretest dicarii perhitungan gain skor. Hasil dari gain skor tersebut diuji dengan uji prasyarat analisis data yang meliputi uji normalitas dan uji homogenitas. Uji normalitas dilakukan untuk mengetahui apakah sebaran data gain skor kompetensi pengetahuan IPA siswa masing-masing kelompok berdistribusi normal atau tidak dengan menggunakan kolmogorovsmirnov dengan kriteria pengujian pada taraf signifikansi 5\%, jika harga nilai maksimum $|\mathrm{Ft}-\mathrm{Fs}|<$ harga nilai tabel kolmogorov-smirnov, maka H0 diterima dan data berdistribusi normal. Sedangkan uji homogenitas dilakukan untuk menunjukkan bahwa perbedaan yang terjadi akibat adanya perbedaan antar kelompok, bukan sebagai akibat perbedaan individu dalam kelompok dengan menggunakan uji $\mathrm{F}$, dengan kriteria pengujian dilakukan pada taraf signifikansi 5\% melalui derajat kebebasan untuk pembilang n1 - 1 dan derajat kebebasan untuk penyebut n2 - 1. jika Fhitung $\leq$ Ftabel maka sampel dinyatakan homogen.

Setelah uji prasyarat dilakukan kemudian dilanjutkan dengan pengujian hipotesis observasi (H0) dengan rumus separated varians. Kriteria pengujian pada taraf signifikansi $5 \%$ dan dk =n1 $+n 2-2$, jika thitung > ttabel , maka HO diterima dan Ha ditolak. Sebaliknya jika thitung > ttabel, maka H0 ditolak dan Ha diterima.

\section{Hasil dan Pembahasan}

Hasil penelitian ini disajikan dalam bentuk deskripsi data kompetensi pengetahuan IPA tema daerah tempat tinggalku pada siswa kelas IV SD Gugus I Kecamatan Gianyar Tahun Pelajaran 2017/2018. Data kompetensi pengetahuan IPA siswa kelompok eksperimen dan kelompok kontrol diperoleh setelah melaksanakan pembelajaran dan menganalisis hasil pretest dan posttest untuk memperoleh data gain skor ternormalisasi. Data yang diperoleh dalam penelitian ini, yakni: (a) data kompetensi pengetahuan IPA siswa kelompok eksperimen, (b) data kompetensi pengetahuan IPA siswa kelompok kontrol. Deskripsi perolehan data pada kelompok eksperimen menunjukkan nilai maksimum gain skor ternormalisasi kompetensi pengetahuan IPA terhadap 30 siswa adalah 0,68 dan nilai minimum 0,26. Data tersebut kemudian dianalisis untuk mengetahui rata-rata (mean) gain skor ternormalisasi kompetensi pengetahuan IPA siswa kelompok eksperimen yakni 0,46 dan standar deviasi 0,1162 serta varians 0,0135. Distribusi frekuensi data gain skor ternormalisasi kompetensi pengetahuan IPA kelompok eksperimen dapat digambarkan dengan histogram sebagai berikut, pada gambar 1 .

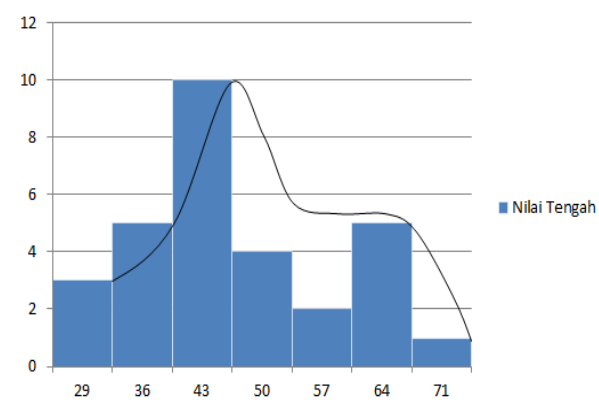

Gambar 1. Histogram Kompetensi Pengetahuan IPA Kelompok Eksperimen 
Deskripsi perolehan data pada kelompok kontrol terhadap 30 siswa menunjukkan nilai maksimum gain skor ternormalisasi kompetensi pengetahuan IPA siswa yakni 0,45 dan nilai minimum yakni 0,10. Data tersebut kemudian dianalisis untuk mengetahui rata-rata (mean) gain skor ternormalisasi kompetensi pengetahuan IPA siswa kelompok kontrol yakni 0,26 dan standar deviasi 0,0860, serta varians yakni 0,0074. Distribusi frekuensi data gain skor ternormalisasi kompetensi pengetahuan IPA kelompok kontrol dapat digambarkan dengan histogram sebagai berikut, pada gambar 2 .

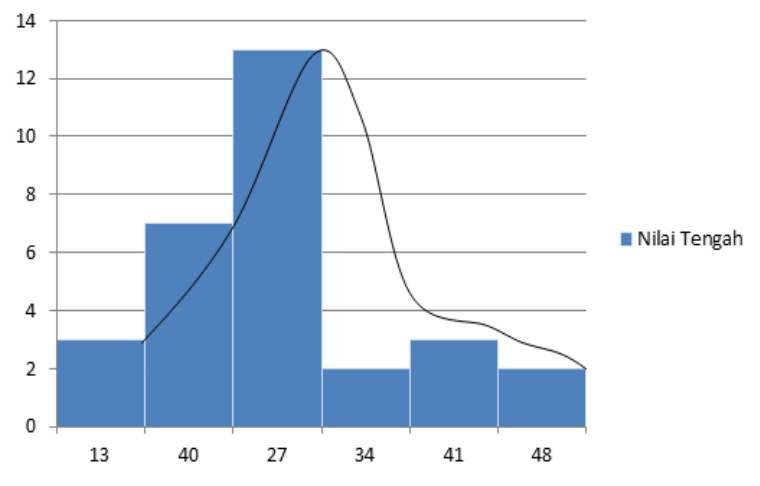

Gambar 2. Histogram Kompetensi Pengetahuan IPA Kelompok Kontrol

Sebelum data penelitian ini dianalisis dengan teknik statistik inferensial menggunakan uji-t, terlebih dahulu dilakukan uji prasyarat analisis terhadap data-data hasil penelitian. Uji prasyarat yang harus dipenuhi adalah sebaran data berdistribusi normal dan varians antar kelompok homogen.

Uji normalitas digunakan dihitung dengan rumus kolmogorv - smirnov. Berdasarkan hasil uji normalitas sebaran data kelompok eksperimen, diperoleh harga nilai maksimum | Ft - Fs | sebagai angka penguji normalitas yaitu, 0,141 < harga tabel Kolmogorv - Smirnov yaitu 0,242, maka sebaran data gain skor ternormalisasi kelompok eksperimen berdistribusi normal. Sedangkan hasil uji normalitas sebaran data kelompok kontrol, diperoleh harga nilai maksimum $\left|F_{t}-F_{s}\right|$ sebagai angka penguji normalitas, yaitu 0,171 < harga tabel Kolmogorov -Smirnov yaitu 0,242 maka sebaran data gain skor ternormalisasi kelompok kontrol berdistribusi normal.

Selanjutnya dilakukan uji homogenitas terhadap varians antar kelompok eksperimen dan kelompok kontrol. Uji homogenitas varians dalam penelitian ini menggunakan uji $\mathrm{F}$ dengan kriteria data homogen jika $F_{\text {hitung }}<F_{\text {tabel. }}$ Berdasarkan hasil dari pengujian homogenitas diperoleh nilai dari $F_{\text {hitung }}$ kompetensi pengetahuan IPA adalah 1,82 sedangkan $F_{\text {tabel }}$ sebesar 1,86 dengan derajat kebeasan untuk pembilang $n_{1}-1(30-1=29)$ dan derajat kebebasan untuk penyebut $n_{2}-1(30-1=29)$ dan taraf signifikan $5 \%$. Hal ini berarti varians data kompetensi pengetahuan IPA kelompok eksperimen dan kelompok kontrol adalah homogen.

Berdasarkan hasil uji normalitas dan sebaran data dan uji homogenitas varians dapat diketahui bahwa data yang diperoleh dari kelompok eksperimen dan kelompok kontrol berdistribusi normal dan memiliki varians yang homogen. Karena data yang diperoleh telah memenuhi uji prasyarat analisis, maka uji hipotesis dapat dilakukan dengan menggunakan analisis uji-t dengan rumus separated varians. Dengan kriteria pengujian jika $t_{\text {hitung }}<\mathrm{t}_{\text {tabel }}$ maka $\mathrm{H}_{0}$ diterima dan $\mathrm{H}_{\mathrm{a}}$ ditolak, dan jika $\mathrm{t}_{\text {hitung }}>\mathrm{t}_{\text {tabel, }}$ maka $\mathrm{H}_{0}$ ditolak dan $\mathrm{H}_{\mathrm{a}}$ diterima pada taraf signifikan $5 \%$ dengan $\mathrm{dk}=\mathrm{n}_{1}+\mathrm{n}_{2}-2$. Rangkuman hasil perhitungan uji-t antara kelompok eksperimen dan kelompok kontrol disajikan pada Tabel 1.

Tabel 1. Hasil Analisis Uji Hipotesis

\begin{tabular}{ccccccccc}
\hline No & $\begin{array}{c}\text { Kelompok } \\
\text { Sampel }\end{array}$ & $\mathrm{N}$ & $\mathrm{Dk}$ & $\begin{array}{c}\text { Rata-rata } \\
\text { Gain Skor }\end{array}$ & $\mathrm{S}^{2}$ & $\mathrm{t}_{\text {hitung }}$ & $\mathrm{t}_{\text {tabel }}$ & Keterangan \\
\hline 1 & Eksperimen & 30 & & 0,46 & 0,0135 & 7,067 & 2,000 & $\mathrm{H}_{0}$ ditolak \\
2 & Kontrol & 30 & 58 & 0,26 & 0,0074 & & & \\
\hline
\end{tabular}


Berdasarkan hasil perhitungan uji-t diperoleh $t_{\text {hitung }}=7,067$. Sedangkan nilai $t_{\text {tabel }}$ pada taraf signifikansi $5 \%$ dengan $\mathrm{dk}=\mathrm{n} 1+\mathrm{n} 2-2=30+30-2=58$ menunjukkan nilai tabel sebesar 2,000. Sehingga diperoleh hasil analisis harga $t_{\text {hitung }}=7,067>t_{\text {tabel }}=2,000$ maka Ho dinyatakan ditolak dan Ha diterima. Hal ini menunjukkan terdapat pengaruh model pembelajaran reciprocal teaching berbasis penilaian kinerja terhadap kompetensi pengetahuan IPA siswa kelas IV SD Gugus I Kecamatan Gianyar tahun pelajaran 2017/2018.

Perolehan hasil perhitungan analisis data yang dilakukan menunjukkan bahwa rata-rata kompetensi pengetahuan IPA siswa kelompok eksperimen $\bar{X}=0,46$ dibandingkan dengan rata-rata kompetensi pengetahuan IPA kelompok kontrol $\bar{X}=0,26$. Jadi kompetensi pengetahuan IPA kelompok eksperimen $\bar{X}=0,46>\bar{X}=0,26$ kelompok kontrol.

Berdasarkan hasil temuan tersebut, dapat dinyatakan kedua kelompok sampel penelitian yang memiliki kemampuan setara, setelah diberikan perlakuan berupa model Reciprocal Teaching berbasis penilaian kinerja dan mengikuti pembelajaran menggunakan pendekatan saintifik diperoleh hasil kompetensi pengetahuan yang berbeda. Hal ini dapat dilihat juga dari rerata siswa yang mengikuti pembelajaran menggunakan model pembelajaran reciprocal teaching lebih tinggi dibandingkan dengan rerata siswa pada kelompok kontrol.

Perbedaan kompetensi pengetahuan pada kelompok eksperimen dan kelompok kontrol disebabkan karena perlakuan berupa model reciprocal teaching berbasis penilaian kinerja pada kelompok eksperimen, memberikan pengalaman kepada siswa untuk mengadakan pembelajaran yang timbal balik, artinya siswa yang belum memahami materi, bisa diajarkan oleh siswa yang sudah memahami materi. Model reciprocal teaching menurut Shoimin (2014:153) mengandung empat strategi, yaitu question generating (mengajukan pertanyaan), clarifying (mengklarifikasi permasalahan), predicting (memprediksi), dan summarizing (menyimpulkan). "Model reciprocal teaching juga memberikan kesempatan bagi siswa untuk menyampaikan informasi kepada siswa lain terkait dengan ringkasan yang telah dibuatnya" (Suteni, 2013:3). Sedangkan pada kelompok kontrol yang menerapkan pembelajaran menggunakan pendekatan saintifik, tidak menggunakan model pembelajaran reciprocal teaching berbasis penilaian kinerja. Pembelajaran yang dilakukan hanya sebatas memperoleh informasi dari buku pegangan yang digunakan, sehingga interaksi antar siswa masih kurang. Hal tersebut juga bisa membuat siswa merasa kurang bersemangat dalam belajar karena pembelajaran masih banyak menggunakan metode ceramah.

Berdasarkan paparan hasil penelitian dan pembahasan tersebut, dapat dikatakan bahwa model pembelajaran Reciprocal Teaching berbasis penilaian kinerja berpengaruh terhadap kompetensi pengetahuan IPA siswa kelas IV SD Gugus I Kecamatan Gianyar tahun pelajaran 2017/2018.

\section{Simpulan dan Saran}

Berdasarkan analisis data dan pembahasan, dapat disimpulkan bahwa model Reciprocal Teaching berbasis penilaian kinerja berpengaruh terhadap kompetensi pengetahuan IPA siswa kelas IV SD Gugus I Kecamatan Gianyar tahun pelajaran 2017/2018. Hal ini terbukti dari analisis data yang menggunakan uji$\mathrm{t}$, diperoleh $\mathrm{t}_{\mathrm{hitung}}=7,067$ sedangkan pada taraf signifikansi $5 \%$ dan $\mathrm{dk}=58$ diperoleh nilai $\mathrm{t}_{\text {tabel }}=2,000$. Karena $t_{\text {hitung }}=7,067>t_{\text {tabel }}=2,000$ maka $\mathrm{H}_{0}$ ditolak dan $\mathrm{H}_{\mathrm{a}}$ yang menyatakan model reciprocal teaching berbasis penilaian kinerja berpengaruh terhadap kompetensi pengetahuan IPA siswa kelas IV SD Gugus I Kecamatan Gianyar Tahun Pelajaran 2017/2018 diterima.

Adapun saran yang ingin disampaikan melalui penelitian ini yaitu: (1) Kepada guru, Berdasarkan hasil penelitian yang diperoleh, disarankan kepada guru agar lebih kreatif dalam merancang pembelajaran, dan guru agar lebih inovatif dalam menerapkan model-model pembelajaran, salah satunya dengan menggunakan model reciprocal teaching. Model pembelajaran dapat dijadikan suatu alternatif dalam proses pembelajaran untuk membantu peserta didik meningkatkan kompetensi pengetahuan IPA. (2) Kepada Sekolah, Berdasarkan hasil penelitian yang diperoleh, disarankan kepada kepala sekolah agar dapat menggunakan hasil penelitian ini sebagai salah satu cara dalam mengelola pembelajaran agar sesuai dengan karakteristik muatan materi IPA, sehingga akan menciptakan suasana pembelajaran yang menyenangkan. (3) Kepada Peneliti Lain, Berdasarkan hasil penelitian yang diperoleh, disarankan kepada peneliti agar hasil penelitian ini digunakan sebagai salah satu referensi untuk melaksanakan penelitian selanjutnya atau sebagai acuan dalam mengembangkan penelitian yang relevan 


\section{Daftar Rujukan}

Agung, A. A.G. 2006. Evaluasi Pendidikan. Singaraja: Institut Keguruan Dan Ilmu Pendidikan Negeri Singaraja.

Agung, A. A. G. 2014. Metodologi Penelitian Pendidikan. Yogyakarta: Aditya Media Publishing.

Agung, A. A. G. 2016. Statistika Dasar untuk Pendidikan. Yogyakarta: Deepublish.

Arikunto, Suharsimi. 2015. Dasar-dasar Evaluasi Pendidikan. Jakarta: Bumi Aksara.

Ariyasa, I Gd. 2014. "Pengaruh Model $\neg$ Pembelajaran Reciprocal Teaching Terhadap Hasil Belajar IPA Siswa Kelas V SD Negeri 1 Tulamben”. E-journal. Jurusan Pendidikan Guru Sekolah Dasar . Volume 2, Nomor 1 (hlm 1- 4), diakses tanggal 08 Februari 2018.

Cahyono, Tri. 2015. Statistik Uji Normalitas. Purwekerto: Yayasan Sanitarian Banyumas.

Dantes. 2012. Metode Penelitian.Yogyakarta: Penerbit Andi.

Dantes. 2017. Desain Eksperimen dan Analisis Data. Depok: Rajawali Pers.

Huda, Miftahul. 2016. Model-model Pengajaran dan Pembelajaran. Yogyakarta: Pustaka Pelajar.

Kunandar. 2014. Penilaian Autentik (Penilaian Hasil Belajar Peserta Didik Berdasarkan Kurikulum 2013). Jakarta: Rajawali Pers.

Kurniasih dan Berlin Sani . 2017. Ragam Pengembangan Model Pembelajaran Untuk Peningkatan Profesionalitas Guru. Surabaya: Kata Pena.

Lestari, dkk. 2017. Penelitian Pendidikan Matematika. Bandung: Refika Aditama.

Mahayanti, Gst. A. Md, dkk. 2013. "Pengaruh Model Pembelajaran Reciprocal Teaching Berbantuan Mind Mapping Terhadap Pemahaman Konsep IPA Siswa elas IV Semester II SD No 1 Baktiseraga”. Jurnal Pendidikan Mimbar PGSD Universitas Pendidikan Ganesha Jurusan PGSD, Volume 1, No 1(hlm 4,) diakses tanggal 10 Februari 2018.

Peraturan Menteri Pendidikan dan Kebudayaan Republik Indonesia Nomor 57 Tentang Kurikulum 2013 Sekolah Dasar, 2014. Jakarta: Kemendikbud.

Samatowa, Usman. 2011. Pembelajaran IPA di Sekolah Dasar. Jakarta Barat : PT Indeks.

Setyosari, Punaji H. 2015. Metode Penelitian Pendidikan dan Pengembangan. Jakarta: Prenada Media Group.

Shoimin, Aris. 2014. 68 Model Pembelajaran Inovatif dalam Kurikulum 2013. Yogyakarta: Ar-ruzz Media.

Suastra, I Wayan. 2017. Pembelajaran Sains Terkini. Singaraja: Universitas Pendidikan Ganesha

Sugiyono. 2016. Statistikia untuk Penelitian. Bandung: Alfa Beta.

Sugiyono. 2017. Metode Penelitian. Bandung: Alfabeta.

Uno Hamzah B dan Satria Koni, 2012. Assessment Pembelajaran. Jakarta: Bumi Aksara 